1 THE EFFECT OF TWO COMMERCIAL ANTIFUNGAL FORMULATIONS ON THE METABOLISM OF A COMMERCIAL SACCHAROMYCES CEREVISIAE STRAIN AND THEIR REPERCUSSION ON FERMENTATION EVOLUTION

\title{
AND PHENYLALANINE CATABOLISM
}

\section{AUTHORS:}

6 Thais Sieiro-Sampedro ${ }^{1}$, Javier Alonso-del-Real ${ }^{2, *}$, Noelia Briz-Cid ${ }^{1}$, Raquel Rial7 Otero $^{1, *}$, Amparo Querol $^{2}$, Jesús Simal-Gandara ${ }^{1}$

8

9 CENTRES:

$10{ }^{1}$ Nutrition and Bromatology Group, Department of Analytical and Food Chemistry, 11 CITACA, Faculty of Science, University of Vigo - Ourense Campus, E32004-Ourense, 12 Spain.

$13{ }^{2}$ Instituto de Agroquímica y Tecnología de los Alimentos, IATA-CSIC, Paterna, E14 46980, Spain 15

16 Thais Sieiro Sampedro (tsieiro@uvigo.es)

17 Javier Alonso-del-Real* (javier.alonso@iata.csic.es)

18 Noelia Briz Cid (nbriz@uvigo.es)

19 Raquel Rial-Otero* (raquelrial@uvigo.es)

20 Amparo Querol (aquerol@iata.csic.es)

21 Jesús Simal-Gandara (jsimal@uvigo.es)

$22 *$ corresponding authors 


\section{ABSTRACT}

26 The effect of two commercial formulations (incorporating mepanipyrim and

27 tetraconazole as active substances) on the metabolism of Saccharomyces cerevisiae

28 Lalvin $\mathrm{T}^{\mathrm{TM}}$, growing on a synthetic grape must, and their influence on the alcoholic

29 fermentation course and the biosynthesis of volatiles derived from phenylalanine

30 catabolism was studied. No essential effects were observed for mepanipyrim except for

31 glycerol production. On the contrary, in the presence of tetraconazole many genes and

32 some proteins related to cell cycle progression and mitosis were repressed. This fact could

33 explain the lower biomass concentration and the lower sugar consumption registered for

34 tetraconazole at the end of the study. However, the biomass-to-ethanol yield was higher

35 in connection with the overexpression of the $A D H 1$ gene. The presence of tetraconazole

36 residues seems to accelerate the Ehrlich pathway. These results agree with the

37 overexpression of several genes (BAT1, PDC1, PDC5, ADH1, SFA1, ATF2, PFK1, PFK2

38 and ARO3) and two proteins (Gap1p and Atf2p) involved in this metabolic pathway.

40 Keywords: fungicides, cell cycle, Ehrlich pathway, aromatic compounds, proteomics, transcriptomics. 


\section{INTRODUCTION}

44 Fungicide residues can modify the structure of the cellular membranes of yeasts, causing sluggish and stuck fermentations (Calhelha et al., 2006; Russo et al., 2019). In this sense, Doignon \& Couty, (1992) observed sluggish fermentations, lower ethanol production and an increment of the frequency of stuck fermentations in the presence of triadimephon, flusilazol and triadimenol. Sluggish fermentations were also obtained in the presence of benomyl (Calhelha et al., 2006). A reduction in the sugars consumption during the first fermentation days was observed after the application of pyrimethanil in vineyards (Čuš \& Raspor, 2008) and also lower specific growth rates were obtained in laboratory scale assays using synthetic must (Gil et al., 2014) Quinoxyfen decreased the ethanol production rate and the sugars-to-ethanol yield (Saaris et al., 2009) while pyraclostrobin increased the ethanol and the biomass production (González-Rodríguez et al., 2011). The sugars-to-ethanol yield was also altered in the presence of ametoctradin, dimethomorph and mepanipyrim (Noguerol-Pato et al., 2014b).

Besides, the presence of fungicide residues in grapes were associated with changes in the aromatic profile of wines (González-Álvarez et al., 2012a, 2012b; Kosel et al., 2018; Noguerol-Pato et al., 2014a, 2015; Oliva et al., 2015). Previous results demonstrated the influence of mepanipyrim and tetraconazole residues on the biosynthesis of higher alcohols and acetates (Sieiro-Sampedro et al., 2019b, 2019a, 2020). Two volatile aromatic compounds desired in wines are 2-phenylethanol and 2-phenylacetate since they have a positive contribution to wine aroma with rose nuances (Swiegers et al., 2005). 2Phenyletanol is generated by yeast from its amino acid precursor -phenylalaninethrough the Ehrlich pathway during the exponential growth phase and later, this compound is oxidised to 2-phenylacetate (Dzialo et al., 2017). These changes being dependent on the fungicide applied and its concentration, the grape variety and the yeast 
68 strain used during the fermentation process. However, mechanisms involved in these changes remain quite unexplored.

Articles focused on the study of the impact of fungicides on Sacharomyces yeast metabolism from a proteomic or a transcriptomic point of view are yet scarce on the literature. Exposure to thiuram induced some genes involved in DNA repair, folding and proteolysis, response to oxidative stress and carbohydrate metabolism (Kitagawa et al., 2002). Pyrimethanil modified the expression of 1667 genes of the $S$. cerevisiae yeast, showing a substantial effect on those genes involved in amino acids metabolism, energy conservation, antioxidant response, and multidrug transport processes (Gil et al., 2014). Mancozeb increased the abundance of antioxidant enzymes, and also the expression of some proteins involved in the carbohydrate metabolism, protein synthesis, and protein degradation (Santos et al., 2009). FLRl gene was identified as a determinant of yeast resistance to mancozeb (Teixeira et al., 2008).

Considering the unavoidable use of fungicides to combat fungal disease on vineyards and their repercussions on the fermentation course and the aromatic profile of wines, a better knowledge of the interactions among nitrogen substrate, yeasts, and fungicides during the alcoholic fermentation is mandatory. Therefore, this work aimed to evaluate the effect of two commercial antifungal formulations (Frupica ${ }^{\circledR}$ and Domark ${ }^{\circledR}$ Evo) on the growth of Lalvin $\mathrm{T}^{\mathrm{TM}}$ yeasts and the biosynthesis of some aromatic compounds derived from the phenylalanine catabolism (phenylacetaldehyde, 2-phenylethanol and 2-phenylacetate). In this way, laboratory-scale assays could be a useful tool to study the effect of these fungicides. Moreover, a synthetic must supplement with phenylalanine as the unique nitrogen source was used for a better understanding of their catabolism. In order to explain the obtained results, proteomic and transcriptomic analysis was done. Additionally, the 
92 effect of both fungicides on other fermentative parameters (such as sugars consumption and ethanol production) and phenylalanine consumption was evaluated.

\section{MATERIALS AND METHODS}

\subsection{Analytical standards, solvents and reagents}

Phenylacetaldehyde ( $\geq 90 \%)$, 2-phenylethanol ( $\geq 99 \%)$ and 2-phenylacetate $(\geq 97 \%)$ analytical standards were purchased from Sigma-Aldrich (Madrid, Spain). Lphenylalanine $(98.5$ - $101.0 \%)$, DL-malic acid Plus ${ }^{\circledR}(99 \%)$, potassium bisulfide Bioultra ( $\geq 97.0 \%)$, Tween ${ }^{\circledR} 80$, glycerol ACS ( $\geq 99.5 \%$ ), acetic acid, sodium azide Plus ${ }^{\circledR}(\geq 99.5 \%$ ), diethyl etoximethylenmalonate (DEEMM, $99 \%$ ), potassium hydroxide ( $\geq 85 \%$ ), sulfuric acid (95-97\%), $\beta$-mercaptoethanol ( $\geq 98 \%$ ), sodium dodecyl sulfate (SDS, suitable for electrophoresis $\geq 98.5 \%$ ), protease inhibitor cocktail, Bradford reagent, Coomassie Brilliant Blue R, DL-Dithiothreitol (DTT, $\geq 99 \%$ ), iodoacetamide (IAA, $\geq 99 \%$ ), trifluoroacetic acid (99\%) and trypsin from porcine pancreas (Proteomics grade) were also from Sigma-Aldrich. D(+)-glucose anhydrous, D(-)-fructose extrapure Pharmpur $^{\circledR}$ and ammonium hydrogen carbonate (reagent grade) were from Scharlab S.L. (Barcelona, Spain). Citric acid monohydrate, sodium hydroxide, boric acid, calcium carbonate, ethylenediaminetetraacetic acid, disodium salt (EDTA, $\geq 99 \%$ ), sodium hydroxide, pellets $(98 \%)$ and yeast extract for microbiology from Panreac S.A. (Barcelona, Spain). BD Difco ${ }^{\mathrm{TM}}$ dehydrated culture media from Becton, Dickinson and Company (Nueva Jersey, EE.UU). Yeast nitrogen base (YNB) without amino acids and ammonium sulphate, ergosterol $(98 \%)$ and sodium oleate $(65-90 \%)$ from ACROS Organics ${ }^{\mathrm{TM}}$ Fisher Scientific (Pittsburgh, EE.UU.). $30 \%$ acrylamide/Bis Solution, 37.5:1 was purchased from Bio-Rad (Hercules, Ca, USA). 
116 Hydrochloric acid (37\%), absolute ethanol Multisolvent ${ }^{\circledR}$ and water for HPLC were from

117 Scharlab S.L. (Barcelona, Spain); methanol, chloroform and dichloromethane

118 Chromasolv ${ }^{\mathrm{TM}}$ for HPLC $(\geq 99.9 \%)$ from Sigma-Aldrich SL and acetonitrile

119 Chromasolv ${ }^{\mathrm{TM}}$ for HPLC ( $\left.\geq 99.9 \%\right)$ from Honeywell Riedel de Haën ${ }^{\mathrm{TM}}$ of Fisher 120 Scientific.

\subsection{Yeast strain and medium}

123 Commercial S. cerevisiae Lalvin $\mathrm{T}^{\mathrm{TM}}$ yeast (hereafter $\mathrm{T} 73$ ) was purchased from

Lallemand Inc (Montreal, Canada). Dried yeast (5 g) was rehydrated in water (50 mL) and cultured during $24 \mathrm{~h}$ at $30{ }^{\circ} \mathrm{C}$ in a YPD-agar medium $(15 \mathrm{~g} / \mathrm{L}$ yeast extract, $20 \mathrm{~g} / \mathrm{L}$ peptone, $20 \mathrm{~g} / \mathrm{L}$ glucose and $15 \mathrm{~g} / \mathrm{L}$ agar). Afterwards, cells were cultured overnight at 30

$127{ }^{\circ} \mathrm{C}$, with orbital agitation $(120 \mathrm{rpm})$, in a YPD medium $(15 \mathrm{~g} / \mathrm{L}$ yeast extract, $20 \mathrm{~g} / \mathrm{L}$ peptone, and $20 \mathrm{~g} / \mathrm{L}$ glucose).

A synthetic must frequently use in microvinification experiments (Martínez-Moreno et al., 2012) with slight modifications was prepared was as follows: $120 \mathrm{~g} / \mathrm{L}$ of glucose, 120 $\mathrm{g} / \mathrm{L}$ of fructose, $0.6 \%$ citric acid, $0.6 \%$ malic acid, $0.17 \%$ of YNB without amino acids and ammonium sulphate, $15 \mathrm{mg} / \mathrm{L}$ of ergosterol, $5 \mathrm{mg} / \mathrm{L}$ of sodium oleate, $0.5 \mathrm{~mL} / \mathrm{L}$ of Tween 80 and $60 \mathrm{mg} / \mathrm{L}$ of potassium disulphide. Phenylalanine at $160 \mathrm{mg} / \mathrm{L}$ was used as the unique nitrogen source. The medium was filtered through nitrocellulose filters $(0.22$ $\mu \mathrm{m})$ and the $\mathrm{pH}$ adjusted to 3.5 with $10 \mathrm{~N} \mathrm{KOH}$.

\subsection{Alcoholic fermentation}

Synthetic must was fermented under semi-anaerobic conditions, in the absence and the presence of the target fungicides (mepanipyrim and tetraconazole), during 9 days at 21 
$140 \quad{ }^{\circ} \mathrm{C}$ with orbital agitation $(120 \mathrm{rpm})$. Triplicate fermentations were carried out using 400 $141 \mathrm{~mL}$ of the synthetic must.

142 Frupica $^{\circledR}(50 \%$ w/w of mepanipyrim $)$ and Domark ${ }^{\circledR}$ Evo $(12.5 \%$ w/v of tetraconazole $)$

143 commercial formulations obtained from Sipcam Iberia (Valencia, Spain) were dissolved

144 in ethanol $(1000 \mu \mathrm{g} / \mathrm{mL})$ and separately added to the fermentation medium. To a better

145 visualisation of the effects, a fungicide concentration level of twice their corresponding 146 maximum residual level (MRL) on wine grapes (4 and $1 \mathrm{mg} / \mathrm{kg}$ for mepanipyrim and 147 tetraconazole, respectively, according to Regulation 396/2005) was used. Before yeast 148 inoculation $\left(10^{6}\right.$ cells $\left./ \mathrm{mL}\right)$, ethanol concentration was standardised to values of $0.4 \%$ in 149 all fermentations, and the fungicide concentration in the medium was confirmed by GC150 MS analysis (González-Rodríguez et al., 2009).

\subsection{Analytical determinations}

\subsubsection{Fermentation parameters}

154 Along the fermentation process, aliquots $(1 \mathrm{~mL})$ of the liquid medium were taken to 155 monitor the fermentation course. Growth curves were followed by measuring culture OD at $650 \mathrm{~nm}\left(\mathrm{OD}_{650 \mathrm{~nm}}\right)$ in a Genova UV-Vis spectrophotometer of Jenway (Essex, England)

157 and results transformed in concentration using a calibration curve. The calibration curve of yeast strain T73 was obtained from successive dilutions of a yeast extract with $\mathrm{OD}_{650}$ $\mathrm{nm}=1$ by representing the $\mathrm{OD}_{650 \mathrm{~nm}}$ at each dilution point $v s$ the concentration of yeasts

160 (cells $/ \mathrm{mL}$ ) determined by plate counting at the same point. In order to confirm the validity of the calibration curve for all the studied conditions, determinations of the concentration of yeast by plate counting were also performed periodically. No interference of ingredients of the antifungal formulation or the secondary metabolites were observed. 
164 In addition, the content of reducing sugars, ethanol, glycerol and acetic acid was

165 determined in a high-performance liquid chromatography (HPLC) model 1200 of Agilent

166 Technologies (Santa Clara, California, USA) equipped with a refraction index detector

167 (RI) and an ICSep Corregel-87H1 (300 x $7.8 \mathrm{~mm}$ i.d.) column of Transgenomic (San

168 Jose, California, USA) following the chromatographic conditions described on González-

169 Rodríguez et al. (2011). For a better monitoring of the fermentation course, other

170 fermentation parameters (maximum specific growth rate $\left(\mu_{\max }\right)$, sugar consumption rate

$171\left(r_{s}\right)$, ethanol production rate $\left(r_{e}\right)$, biomass-to-ethanol yield $\left(\mathrm{Y}_{\mathrm{E} / \mathrm{B}}\right)$, and sugar-to-ethanol

172 yield $\left(\mathrm{Y}_{\mathrm{E} / \mathrm{S}}\right)$ ) were calculated as described on González-Rodríguez et al., (2011) and

173 Sieiro-Sampedro et al., (2019b).

\subsubsection{Phenylalanine concentration}

176 In order to determine the amino acid consumption rate, liquid samples were taken at

177 different times along the fermentation process. Before chromatographic analysis, samples

178 (1 mL) were centrifuged (5 min at $4000 \mathrm{rpm})$ and derivatised with DEEMM in a borate 179 medium ( $\mathrm{pH}$ 9) for 30 min using a Cleanosonic model 3510 ultrasonic bath of Branson 180 (Wareham, Massachusetts, USA). The excess of DEEMM was removed by heating the samples at $70-80^{\circ} \mathrm{C}$ for two hours (Gómez-Alonso et al., 2007).

182 Phenylalanine concentration was determined in a liquid chromatograph from Thermo 183 Separation-Products (Massachusetts, USA) equipped with an SCM1000 vacuum 184 membrane degasser, a P4000 quaternary pump, a TSP AS3000 autosampler, and a 185 Surveyor PDA plus detector linked to a computer running the Xcalibur version 2.2 186 software program (Thermo Fisher Scientific). An Hypersil Gold C18 (100 x 4.6 mm i.d., $1875 \mu \mathrm{m})$ analytical column with a Pelliguard LC-18 (50 x $4.6 \mathrm{~mm}$ i.d.) guard column of 188 Supelco (Bellefonte, Pennsylvania, USA) was used with a flow rate of $1 \mathrm{~mL} / \mathrm{min}$. The 
189

212

mobile phase was $25 \mathrm{mM}$ acetate buffer ( $\mathrm{pH} 5.8$ ) with $0.4 \mathrm{~g}$ of sodium azide (A) and a

190 mixture 80:20 (v:v) of acetonitrile and methanol (B) with the following gradient

191 conditions: $10 \%$ of B for 2 min, from 10 to $90 \%$ of B in 8 min, from 90 to $10 \%$ in 2 min

192 and keep the initial conditions for $10 \mathrm{~min}$ for reconditioning the column. initially applied (Levene test), followed by an analysis of variance (ANOVA) and a Tukey's honestly significant differences test.

\subsubsection{Volatile compounds}

The concentration of 2-phenylethanol was determined by direct injection following the method of Peinado et al. (2004) with slight modifications. Samples were injected in the split mode (1:10) in a gas chromatograph equipped with a flame ionisation detector (GCFID) from Thermo Fisher Scientific. Concentrations of phenylacetaldehyde and 2phenylacetate were also determined by GC-FID after liquid-liquid extraction of the samples according to the protocol described by Ortega et al. (2001). Volatile compounds were separated in an HP-INNOWAX (60 m x $0.25 \mathrm{~mm}$ i.d.; $0.25 \mu \mathrm{m})$ analytical column from Agilent Technologies using the temperature program described by GonzálezÁlvarez et al. (2012). Helium was used as carrier gas (1.2 mL/min) and an air/hydrogen ratio of $10 / 1$ (350 and $35 \mathrm{~mL} / \mathrm{min})$. Injector and detector temperatures were $250{ }^{\circ} \mathrm{C}$.

\subsubsection{Statistical analysis}

All results were expressed as means \pm standard deviations $(n=3)$. The Statgraphics Centurion XV 15.2.05 Software (Statpoint Technologies, Inc., Warrenton, VA, USA) was used to finding statistically significant differences. Homogeneity of variances test was

\subsection{Transcriptomic analysis}


214 Yeast cells were collected at three different fermentation times (10 h, $36 \mathrm{~h}$, and $48 \mathrm{~h}$ ).

215 Differences in detected metabolites synthesised by yeast are expected to be caused by

216 previous transcriptomics response to fungicides that would affect metabolism; therefore,

217 early time points of fermentation were selected. Yeasts were centrifuged, snap-frozen in

218 liquid nitrogen, and stored at $-80{ }^{\circ} \mathrm{C}$ until use. RNA isolation was performed as described

219 in (Alonso-del-Real et al., 2019) with slight modifications. Despite the kit

220 recommendation to digest the yeast cell wall by the enzymatic reaction, a mechanic

221 procedure was followed instead. It consisted of 3 x 30 seconds bead-beating steps using

222 acid-washed glass beads, alternating with 1 minute resting on ice. RNAseq libraries were

223 generated using the TruSeq Stranded mRNA Library Preparation Kit (Illumina,

224 California, USA) and sequenced on a NextSeq Sequencing System from Illumina (2 x 75

225 bp). Raw files were deposited under the BioProject.

226 Sequence reads were mapped to the S. cerevisiae T73 genome using Bowtie2 v. 2.2.9

227 (Langmead and Salzberg, 2012) and the read counts for each gene were obtained with the

228 HTSeq-Count (HTSeq-0.6.1p1, -m intersection-nonempty) (Anders et al., 2015). An

229 average of 2.9 million reads per sample and a median of 245 reads per gene were obtained.

230 Differential gene expression analysis was performed using the R package DESeq2 (Love

231 et al., 2014) and the Wald tests as previously described on (Alonso-del-Real et al., 2019).

232 For this, every fungicide treatment at every time point was compared with the control at

233 the same time point.

234

235 2.6. Proteomic analysis

236 Sample collection for proteomic analysis was made at the same times and in the same

237 way described above for the gene expression analysis. Soluble protein extracts were 238 obtained following the extraction method proposed by Von der Haar (2007). Then, $20 \mu \mathrm{g}$ 
239 of total protein per sample was loaded on a sodium dodecyl sulphate polyacrylamide gel $240(12 \%)$ and concentrated in a small piece of gel using a Mini-PROTEAN ${ }^{\circledR}$ Tetra vertical 241 electrophoresis cell from Bio-Rad (Hercules, California, USA). Protein bands were 242 excised and subjected to an overnight in-gel digestion protocol with trypsin (40 ng) after 243 a reduction $\left(10 \mathrm{mM}\right.$ dithiothreitol at $\left.56^{\circ} \mathrm{C}\right)$ and alkylation $(55 \mathrm{mM}$ iodoacetamide at room 244 temperature) step. Tryptic peptides were extracted from the gel matrix once with $0.5 \%$ 245 trifluoroacetic acid and twice with acetonitrile. Before LC-MS/MS analysis, samples 246 were evaporated to dryness, resuspended in LC/MS-grade water $(24 \mu \mathrm{L})$ containing 0.1 $247 \%(\mathrm{v} / \mathrm{v})$ of formic acid and centrifuged (14000 rpm, $5 \mathrm{~min})$.

248 Tryptic digests $(12 \mu \mathrm{L})$ were separated on a PepMap ${ }^{\circledR}$ RSCL C18 reverse-phase column $249(75 \mu \mathrm{m} x 50$ cm, $2 \mu \mathrm{m}, 100 \AA$ ) using a Proxeon Easy-nLC 1000 UHPLC system (Thermo 250 Fisher Scientific, Waltham, MA USA). Acidified water (0.1\% of formic acid) and 251 acidified acetonitrile $(0.1 \%$ of formic acid) were used as mobile phase $\mathrm{A}$ and $\mathrm{B}$, 252 respectively, increasing the percentage of B from 5 to $30 \%$ in $240 \mathrm{~min}$ at a flow rate of $2535 \mu \mathrm{L} / \mathrm{min}$. Elutes were analysed by electrospray ionisation tandem mass spectrometry on 254 a hybrid high-resolution LTQ-Orbitrap Elite Mass Spectrometer from Thermo Fisher 255 Scientific using the following parameters: positive ion mode, data-dependent scan, mass 256 range from $380-1600 \mathrm{~m} / \mathrm{z}, 15-38 \%$ of the normalised collision energy, dynamic 257 exclusion time of $30 \mathrm{~s}$, minimum signal threshold of 1000 , and isolation width of 1.50 258 Da.

259 Proteome Discoverer (Thermo Fisher Scientific) software was used to protein 260 identification against NCBIProt database from $S$. cerevisiae and label-free relative 261 quantification, using a decoy sequence database to calculate the false discovery rate 262 (FDR). The following parameters were used for positive protein identification: precursor mass tolerance $8 \mathrm{ppm}$, fragment mass tolerance $4 \mathrm{Da}$, number of matched peptide 
264 sequences $\geq 1$, and peptide-spectrum matches (PSMs) $<0.5 \%$ FDR. The QuickGO

265 software from $\quad$ EMBL-European $\quad$ Bioinformatics $\quad$ Institute

266 (https://www.ebi.ac.uk/QuickGO/) was used for functional annotation while the Perseus

267 software (https://maxquant.net/perseus/) was used to detect statistically significant

268 differences $(p$-value $<0.01)$ between treated and control yeasts.

\section{RESULTS AND DISCUSSION}

\subsection{Effect of fungicides on the yeast growth}

272 Under the studied conditions, yeast showed a lag phase lower than $10 \mathrm{~h}$ (Figure 1).

273 During the exponential growth phase (1-3 days), the presence of fungicides did not affect

274 biomass production, obtaining a $\mu_{\max }$ value around 2.1 days $^{-1}$ for all experiments.

275 However, the behaviour of both fungicides during the stationary phase was different.

276 Yeast inoculated on a mepanipyrim-enriched medium showed a similar growth trend to

277 those growing in the control medium (without fungicides). Similar results were obtained

278 for other fungicides (González-Rodríguez et al., 2011; Noguerol-Pato et al., 2014b; Saaris

279 et al., 2009), including the fungicide pyrimethanil belonging to the same chemical family

280 that mepanipyrim (Čuš and Raspor, 2008).

281 However, in the presence of tetraconazole residues, a significant reduction of the total

282 biomass concentration during the stationary phase was observed $\left(112.4 \times 10^{6} \pm 3.37\right) v s$

$283121.6 \times 10^{6} \pm 1.96$ cells $/ \mathrm{mL}$ ). These results agree with those reported for tebuconazole,

284 another triazole fungicide, for which a reduction on the maximum biomass production

285 was observed (González-Rodríguez et al., 2009b). However, no effects on biomass

286 production were observed for the triazole fungicide fluquinconazole (Oliva et al., 2007).

287 These results agree with our transcriptomic and proteomic data. As it can be seen in

288 Figure 2, many genes and some proteins related to cell cycle progression and mitosis 
289

290 and $\mathbf{S 2}$ of the supplementary material). Cell cycle was the main enriched functional

291 category for this group of samples (GO, biological process, $p$-value $\left.=1.03 \times 10^{-11}\right)$, and it

292 was not the only one related to these process. Especially, mitotic spindle organisation in 293 the nucleus $\left(5.45 \times 10^{-9}\right)$ and chromosome segregation $\left(3.76 \times 10^{-8}\right)$ seem to be the most

294 repressed steps, with the most important number of genes present. Moreover, essential 295 activators of Cdc28p by phosphorylation such as $C L N 1, C K S 1, M I H 1$, and $C A K 1$, that are key to cell cycle progression regulation were also repressed.

\subsection{Effect of fungicides on fermentative parameters}

300 Several indices were calculated to describe the fermentation course in presence and absence of each one of the target fungicides (Table 1).

- Sugar consumption rate $\left(\mathrm{r}_{\mathrm{s}}\right)$. Sugars consumption followed a sigmoidal-decay response and no significant effects of fungicides were detected on this parameter during the exponential growth phase (Table 1) as previously reported by other authors (Noguerol-Pato et al., 2014b; D. Saaris et al., 2009). At the end of the study (9 days), 20.5 $\%$ and $58.6 \%$ of the initial glucose and fructose, respectively, remain in the control medium. However, the final concentration of glucose was significantly higher in the

310 already reported repression of cell cycle progression, which would involve less cell density and, consequently, a lower sugar consumption.

312 Moreover, differential expression of several genes encoding for sugar transporter was 313 obtained. High-affinity sugar transporters $H X T 2$ and $H X T 4$ were down-regulated and 
314 low-affinity sugar transporters $H X T 1$ and $H X T 3$ were overexpressed in the fermentation

315 treated with tetraconazole concerning the control. Sugars concentration in the media is

316 one of the main factor driving the expression of the different sugar transporters in yeast.

317 Low-affinity transporters are more actively expressed at the initial stages of wine

318 fermentation, while high-affinity transporters tend to appear at the end of the process

319 when nearly all sugars have been consumed (Perez et al., 2005). In our case, as we

320 mentioned, tetraconazole treated fermentations present higher levels of sugars than the

321 control, which could be the reason for this set of genes differential expression.

322 On the contrary, the consumption of sugars in the mepanipyrim-enriched medium was

323 similar to the control. No influence of aniline pyrimidine fungicides on the reducing 324 sugars concentration was previously reported by (Čuš and Raspor, 2008).

- Ethanol production rate. While no effects were found for mepanipyrim, a lower ethanol production rate was observed during the exponential growth phase in the tetraconazole-enriched medium in comparison to the control (Table 1). However, as it can be seen in Figure 1, the maximum ethanol content achieved at the end of the study was similar for all fermentations (around 57.0 - $59.5 \mathrm{mg} / \mathrm{L}$ ). These results agree with those reported for tebuconazole (González-Rodríguez et al., 2009b). For a better analysis of the effect of fungicides on ethanol production, the $\mathrm{Y}_{\mathrm{E} / \mathrm{B}}$ and the $\left(\mathrm{Y}_{\mathrm{E} / \mathrm{S}}\right)$ parameters were calculated.

As expected, a higher $\mathrm{Y}_{\mathrm{E} / \mathrm{B}}$ was obtained in the presence of tetraconazole, while no statistically significant differences were obtained for mepanipyrim. $\mathrm{Y}_{\mathrm{E} / \mathrm{B}}$ increment could be related with the overexpression of $A D H 1$ (an alcohol dehydrogenase involved in the reduction of acetaldehyde to ethanol) registered in the presence of tetraconazole residues after $48 \mathrm{~h}$ of fermentation. 
For $\mathrm{Y}_{\mathrm{E} / \mathrm{S}}$, no significant effects were observed for anyone of the target fungicides. In

340 previous work, lower ethanol production and lower $\mathrm{Y}_{\mathrm{E} / \mathrm{B}}$ and $\mathrm{Y}_{\mathrm{E} / \mathrm{S}}$ were observed in both

341 a commercial pasteurised must and a Tempranillo red must fermented by S. cerevisiae

342 strain VRB in the presence of mepanipyrim (Noguerol-Pato et al., 2014a). The different

343 behaviour between both studies could be attributed to differences in the fermentation

344 media (a more restrictive medium was used in this work) and also to the fungicide

345 concentration assayed ( $3 \mathrm{mg} / \mathrm{kg} v s 4 \mathrm{mg} / \mathrm{kg}$ in this work).

- Glycerol production: a higher glycerol production was observed in the presence of

348 mepanipyrim residues in comparison with the control experiment $(7.8$ vs $6.7 \mathrm{mg} / \mathrm{L}$, after

3499 days of fermentation) while no effects were observed for tetraconazole. Proteomic 350 analysis of yeast growing in the mepanipyrim-enriched medium showed a higher 351 presence of the enzyme Gpd2p, responsible for the formation of glycerol-3-phosphate in 352 the glycerol synthesis pathway. Furthermore, the gene RHR2, coding for the enzyme that 353 synthesises glycerol from glycerol-3-phosphate, was overexpressed according to our 354 transcriptomic analysis. Nevertheless, contradictory results were obtained for other genes 355 and proteins involved in glycerol metabolism. Therefore, for a better understanding of the 356 influence of mepanipyrim on glycerol formation, transcriptomic analysis in later stages 357 of fermentation would have been probably needed.

\subsection{Effect of fungicides on the phenylalanine consumption}

360 Amino acid concentration decreased exponentially during the first three days of the 361 fermentation process and was practically consumed at this point (Table S3 of the 362 supplementary material). The presence of tetraconazole residues seemed to stimulate 
363 phenylalanine consumption concerning the control experiment, being its consumption 364 statistically different only at $48 \mathrm{~h}$.

365

\subsection{Effect of fungicides on aroma biosynthesis}

367 From a quantitative point of view, higher alcohols are the main aromatic compounds 368 produced by yeast through the Ehrlich pathway (Hazelwood, Daran, Van Maris, Pronk, $369 \&$ Dickinson, 2008). This route is also an alternative mechanism for NADH regeneration 370 and adjusts the redox equilibrium in the cell (Van Dijken and Scheffers, 1986). The

371 production of 2-phenylethanol through this pathway involves three steps: a 372 transamination step to form the $\alpha$-keto-phenylpyruvate, a decarboxylation step to from 373 phenylacetaldehyde followed by a reduction step to form the higher alcohol. Afterwards, 374 this alcohol can react with acetyl-CoA to form the corresponding ester, 2-phenylacetate 375 (Etschmann et al., 2002; Hazelwood et al., 2008).

376 Phenylacetaldehyde concentration increased quickly during the first $10 \mathrm{~h}$ of fermentation 377 and then decreased to produce 2-phenylethanol (Figure 3). As expected, the production 378 of 2-phenylethanol was directly proportional to the phenylalanine consumption; 379 corroborating that the production of this higher alcohol through the Ehrlich pathway was 380 amino acid concentration-dependent (Fleet, 2003). Production of 2-phenylacetate was 381 registered from $36 \mathrm{~h}$ of fermentation, increasing its concentration slightly from this point. 382 A similar trend was observed in the presence of the target fungicides. Although no 383 significant differences were observed in the phenylacetaldehyde concentration at each 384 sampling time between treatments and the control experiment, it is essential to remark 385 that its production was higher in the presence of tetraconazole residues (113.2 vs 89.1 $386 \mathrm{mg} / \mathrm{L}$ at $10 \mathrm{~h}$ ) and that it was reduced in a higher proportion during the first day (Figure 387 3). Concerning 2-phenylacetate production, significant differences were observed for 
407

389 experiment (increments between 5-13\%). Slightly higher content of this compound was

390 also found at the final point of this study $(216 \mathrm{~h})$, but not statistically significant. In this

391 sense, the presence of tetraconazole residues seems to accelerate the interconversion of

392 phenylacetaldehyde into 2-phenylacetate through the Ehrlich pathway.

393 Interestingly, as it can be seen in Figure 4, analysis of the differentially expressed genes

394 after $48 \mathrm{~h}$ of fermentation in the tetraconazole-enriched medium (Table S1 of the supplementary material) revealed the overexpression of several genes (BAT1, PDC1,

(Mason \& Dufour, 2000; Verstrepen et al. 2003). impact on cell cycle progression and mitosis, especially after $48 \mathrm{~h}$ of fermentation. Mitotic spindle organisation in nucleus and chromosome segregation seem to be the most

412 repressed steps. Moreover, essential activators of Cdc28p were down-regulated. 413 Consequently, lower biomass production during the stationary phase was observed. 
414 Furthermore, tetraconazole residues promoted overexpression of several genes and 415 proteins involved in the biosynthesis of aromatic compounds derived from the Ehrlich 416 pathway (phenylacetaldehyde, 2-phenylethanol, and 2-phenylacetate). However, at the

417 end of the study, no significant differences in their concentration were found between the 418 fermented control must (without fungicides) and the tetraconazole fermented must.

419 On the contrary, no significant influence of mepanipyrim on S. cerevisiae T73 cell cycle 420 progression, the fermentation parameters, and the biosynthesis of aromatic compounds 421 derived from the Ehrlich pathway was observed.

422

423 Acknowledgements

424 This work received financial support from European Union FEDER funds and the 425 Spanish Ministry of Economy and Competitiveness (AGL2015-66491-C2-1-R). T. 426 Sieiro-Sampedro and N. Briz-Cid would like to thank their predoctoral fellowships by the 427 Xunta de Galicia and the Spanish Researchers Resources Program, respectively.

428

429 Conflict of interest

430 The authors declare that they have no conflict of interest.

REFERENCES:

433

Alonso-del-Real, J., Pérez-Torrado, R., Querol, A., Barrio, E., 2019. Dominance of wine Saccharomyces cerevisiae strains over S. kudriavzevii in industrial fermentation competitions is related to an acceleration of nutrient uptake and utilization. Environ. Microbiol. 21, 1627-1644. https://doi.org/10.1111/1462-2920.14536

Anders, S., Pyl, P.T., Huber, W., 2015. HTSeq-A Python framework to work with highthroughput sequencing data. Bioinformatics 31, 166-169. https://doi.org/10.1093/bioinformatics/btu638

Calhelha, R.C., Andrade, J. V., Ferreira, I.C., Estevinho, L.M., 2006. Toxicity effects of 
fungicide residues on the wine-producing process. Food Microbiol. 23, 393-398. https://doi.org/10.1016/j.fm.2005.04.008

Čuš, F., Raspor, P., 2008. The effect of pyrimethanil on the growth of wine yeasts. Lett. Appl. Microbiol. 47, 54-59. https://doi.org/10.1111/j.1472-765X.2008.02383.x

Dickinson, J.R., Salgado, L.E.J., Hewlins, M.J.E., 2003. The catabolism of amino acids to long chain and complex alcohols in Saccharomyces cerevisiae. J. Biol. Chem. 278, 8028-8034. https://doi.org/10.1074/jbc.M211914200

Doignon, F., Couty, C., 1992. Action des inhibiteurs de la biosynthèse de l'ergostérol sur la fermentation alcoolique du moût de raisin blanc. OENO One 26, 87. https://doi.org/10.20870/oeno-one.1992.26.2.1198

Dzialo, M.C., Park, R., Steensels, J., Lievens, B., Verstrepen, K.J., 2017. Physiology, ecology and industrial applications of aroma formation in yeast. FEMS Microbiol. Rev. 41, S95-S128. https://doi.org/10.1093/femsre/fux031

Etschmann, M., Bluemke, W., Sell, D., Schrader, J., 2002. Biotechnological production of 2-phenylethanol. Appl. Microbiol. Biotechnol. 59, 1-8. https://doi.org/10.1007/s00253-002-0992-x

Fleet, G.H., 2003. Yeast interactions and wine flavour. Int. J. Food Microbiol. 86, 11-22. https://doi.org/10.1016/S0168-1605(03)00245-9

Gil, F.N., Becker, J.D., Viegas, C.A., 2014. Potential mechanisms underlying response to effects of the fungicide pyrimethanil from gene expression profiling in saccharomyces cerevisiae. J. Agric. Food Chem. 62, 5237-5247. https://doi.org/10.1021/jf5007775

Gómez-Alonso, S., Hermosín-Gutiérrez, I., García-Romero, E., 2007. Simultaneous HPLC analysis of biogenic amines, amino acids, and ammonium ion as aminoenone derivatives in wine and beer samples. J. Agric. Food Chem. 55, 608-613. https://doi.org/10.1021/jf062820m

González-Álvarez, M., González-Barreiro, C., Cancho-Grande, B., Simal-Gándara, J., 2012a. Impact of phytosanitary treatments with fungicides (cyazofamid, famoxadone, mandipropamid and valifenalate) on aroma compounds of Godello $\begin{array}{llll}\text { white } & \text { wines. } & \text { Food } & \text { 8hem. }\end{array}$ 
https://doi.org/10.1016/j.foodchem.2011.09.053

González-Álvarez, M., Noguerol-Pato, R., González-Barreiro, C., Cancho-Grande, B., Simal-Gándara, J., 2012b. Changes of the sensorial attributes of white wines with the application of new anti-mildew fungicides under critical agricultural practices. Food Chem. 130, 139-146. https://doi.org/10.1016/j.foodchem.2011.07.018

González-Rodríguez, R.M., Cancho-Grande, B., Simal-Gándara, J., 2009a. Multiresidue determination of 11 new fungicides in grapes and wines by liquid-liquid extraction/clean-up and programmable temperature vaporization injection with analyte protectants/gas chromatography/ion trap mass spectrometry. J. Chromatogr. A 1216, 6033-6042. https://doi.org/10.1016/j.chroma.2009.06.046

González-Rodríguez, R.M., Cancho-Grande, B., Torrado-Agrasar, A., Simal-Gándara, J., Mazaira-Pérez, J., 2009b. Evolution of tebuconazole residues through the winemaking process of Mencía grapes. Food Chem. 117, 529-537. https://doi.org/10.1016/j.foodchem.2009.04.030

González-Rodríguez, R.M., González-Barreiro, C., Rial-Otero, R., Regueiro, J., TorradoAgrasar, A., Martínez-Carballo, E., Cancho-Grande, B., 2011. Influence of new fungicides - Metiram and pyraclostrobin - On Saccharomyces cerevisiae yeast growth and alcoholic fermentation course for wine production. CYTA - J. Food 9, 329-334. https://doi.org/10.1080/19476337.2011.604135

González Álvarez, M., Noguerol-Pato, R., González-Barreiro, C., Cancho-Grande, B., Simal-Gándara, J., 2012. Changes of the sensorial attributes of white wines with the application of new anti-mildew fungicides under critical agricultural practices. Food Chem. 130, 139-146. https://doi.org/10.1016/j.foodchem.2011.07.018

Gutiérrez-Linares, A., 2013. Nitrogen metabolism in wine yeast during alcoholic fermentation: effect on growth, fermentation activity and aroma production. Universitat Politécnica de Valencia.

Hazelwood, L.A., Daran, J.M., Van Maris, A.J.A., Pronk, J.T., Dickinson, J.R., 2008. The Ehrlich pathway for fusel alcohol production: A century of research on Saccharomyces cerevisiae metabolism (Applied and Environmental Microbiology (2008) 74, 8, (2259-2266)). Appl. Environ. Microbiol. 74, 3920. https://doi.org/10.1128/AEM.00934-08 
502 Kitagawa, E., Takahashi, J., Momose, Y., Iwahashi, H., 2002. Effects of the pesticide

503

504

505

506

507

508

509

510

511

512

513

514

515

516

517

518

519

520

521

522

523

524

525

526

527

528

529

530

531

thiuram: Genome-wide screening of indicator genes by yeast DNA microarray. Environ. Sci. Technol. 36, 3908-3915. https://doi.org/10.1021/es015705v

Kosel, J., Raspor, P., Čadež, N., 2018. Maximum residue limit of fungicides inhibits the viability and growth of desirable non-Saccharomyces wine yeasts. Aust. J. Grape Wine Res. 43-52. https://doi.org/10.1111/ajgw.12364

Langmead, B., Salzberg, S.L., 2012. Fast gapped-read alignment with Bowtie 2. Nat. Methods 9, 357-9. https://doi.org/10.1038/nmeth.1923

Love, M.I., Huber, W., Anders, S., 2014. Moderated estimation of fold change and dispersion for RNA-seq data with DESeq2. Genome Biol. 15, 550. https://doi.org/10.1186/s13059-014-0550-8

Magasanik, B., Stanbrough, M., 1995. Transcriptional and posttranslational regulation of the general amino acid permease of Saccharomyces cerevisiae. J. Bacteriol. 177, 94-102.

Martínez-Moreno, R., Morales, P., Gonzalez, R., Mas, A., Beltran, G., 2012. Biomass production and alcoholic fermentation performance of Saccharomyces cerevisiae as a function of nitrogen source. FEMS Yeast Res. 12, 477-485. https://doi.org/10.1111/j.1567-1364.2012.00802.x

Mason, A.B., Dufour, J.P., 2000. Alcohol acetyltransferases and the significance of ester synthesis in yeast. Yeast 16, 1287-1298. https://doi.org/10.1002/10970061(200010)16:14<1287::AID-YEA613>3.0.CO;2-I

Noguerol-Pato, R., Sieiro-Sampedro, T., González-Barreiro, C., Cancho-Grande, B., Simal-Gándara, J., 2015. Evaluation of the effect of fenhexamid and mepanipyrim in the volatile composition of Tempranillo and Graciano wines. Food Res. Int. 71, 108-117. https://doi.org/10.1016/j.foodres.2015.02.025

Noguerol-Pato, R., Sieiro-Sampedro, T., González-Barreiro, C., Cancho-Grande, B., Simal-Gándara, J., 2014a. Effect on the aroma profile of graciano and tempranillo red wines of the application of two antifungal treatments onto vines. Molecules 19, 12173-12193. https://doi.org/10.3390/molecules190812173

Noguerol-Pato, R., Torrado-Agrasar, A., González-Barreiro, C., Cancho-Grande, B., 
Simal-Gándara, J., 2014b. Influence of new generation fungicides on Saccharomyces cerevisiae growth, grape must fermentation and aroma biosynthesis. Food Chem. 146, 234-241. https://doi.org/10.1016/j.foodchem.2013.09.058

Oliva, J., Cayuela, M., Paya, P., Martinez-Cacha, A., Camara, M.A., Barba, A., 2007. Influence of fungicides on grape yeast content and its evolution in the fermentation. Commun Agric Appl Biol Sci 72, 181-189.

Oliva, J., Martínez-Gil, A.M., Lorenzo, C., Cámara, M.A., Salinas, M.R., Barba, A., Garde-Cerdán, T., 2015. Influence of the use of fungicides on the volatile composition of Monastrell red wines obtained from inoculated fermentation. Food Chem. 170, 401-406. https://doi.org/10.1016/j.foodchem.2014.08.056

Ortega, C., López, R., Cacho, J., Ferreira, V., 2001. Fast analysis of important wine volatile compounds - Development and validation of a new method based on gas chromatographic-flame ionisation detection analysis of dichloromethane microextracts. J. Chromatogr. A 923, 205-214. https://doi.org/10.1016/S00219673(01)00972-4

Peinado, R.A., Moreno, J.A., Muñoz, D., Medina, M., Moreno, J., 2004. Gas chromatographic quantification of major volatile compounds and polyols in wine by direct injection. J. Agric. Food Chem. 52, 6389-6393. https://doi.org/10.1021/jf049369o

Perez, M., Luyten, K., Michel, R., Riou, C., Blondin, B., 2005. Analysis of hexose carrier expression during wine fermentation: both low- and high-affinity Hxt transporters are expressed. FEMS Yeast Res. 5, 351-361. https://doi.org/10.1016/j.femsyr.2004.09.005

Russo, P., Berbegal, C., De Ceglie, C., Grieco, F., Spano, G., Capozzi, V., 2019. Pesticide residues and stuck fermentation in wine: new evidences indicate the urgent need of $\begin{array}{llll}\text { tailored } & \text { regulations. } & \text { Fermentation }\end{array}$ https://doi.org/10.3390/fermentation5010023

Saaris, D., Kotseridis, Y., Linga, M., Galiotou-Panayotou, M., Papanikolaou, S., 2009. Enhanced ethanol production, volatile compound biosynthesis and fungicide removal during growth of a newly isolated Saccharomyces cerevisiae strain on enriched pasteurized grape musts. Eng. Life Sci. 9, 29-37. 
564

565

566

567

568

569

570

571

572

573

574

575

576

577

578

579

580

581

582

583

584

585

586

587

588

589

590

591

592

593

Santos, P.M., Simões, T., Sá-correia, I., 2009. Insights into yeast adaptive response to the agricultural fungicide mancozeb: A toxicoproteomics approach 657-670. https://doi.org/10.1002/pmic.200800452

Sieiro-Sampedro, T., Figueiredo-González, M., González-Barreiro, C., Simal-Gandara, J., Cancho-Grande, B., Rial-Otero, R., 2019a. Impact of mepanipyrim and tetraconazole in Mencía wines on the biosynthesis of volatile compounds during the winemaking process. Food Chem. 300,

125223. https://doi.org/10.1016/j.foodchem.2019.125223

Sieiro-Sampedro, T., Pose-Juan, E., Briz-Cid, N., Figueiredo-González, M., TorradoAgrasar, A., González-Barreiro, C., Simal-Gándara, J., Cancho-Grande, B., RialOtero, R., 2019b. Mepanipyrim residues on pasteurized red must influence the volatile derived compounds from Saccharomyces cerevisiae metabolism. Food Res. Int. 126, 108566. https://doi.org/10.1016/j.foodres.2019.108566

Sieiro-Sampedro, T., Briz-Cid, N., Pose-Juan, E., Figueiredo-González, M., GonzálezBarreiro, C., Simal-Gándara, J., Cancho-Grande, B., Rial-Otero, R., 2020. Tetraconazole alters the methionine and ergosterol biosynthesis pathways in Saccharomyces cerevisiae yeasts promoting changes on volatile derived compounds. Food Res. Int. In press.

Swiegers, J.H., Bartowsky, E.J., Henschke, P.A., Pretorius, I.S., 2005. Yeast and bacterial modulation of wine aroma and flavour. Aust. J. Grape Wine Res. 11, 139-173. https://doi.org/10.1111/j.1755-0238.2005.tb00285.x

Teixeira, M.C., Dias, P.J., Simões, T., Sá-Correia, I., 2008. Yeast adaptation to mancozeb involves the up-regulation of FLR1 under the coordinate control of Yap1, Rpn4, Pdr3, and Yrr1. Biochem. Biophys. Res. Commun. 367, 249-255. https://doi.org/10.1016/j.bbrc.2007.12.056

Van Dijken, J.P., Scheffers, W.A., 1986. Redox balances in the metabolism of sugars by yeasts. FEMS Microbiol. Lett. 32, 199-224.

Verstrepen, K. J., Derdelinckx, G., Dufour, J. P., Winderickx, J., Thevelein, J. M., Pretorius, I. S., \& Delvaux, F.R. (2003). Flavor-Active Esters : Adding Fruitiness to Beer. Journal of Bioscience and Bioengineering, 96(2), 110-118. 
594 Von der Haar, T. (2007). Optimized protein extraction for quantitative proteomics of $595 \quad$ yeasts. PLoSONE 2(10): e1078.

596 


\section{FIGURE CAPTIONS:}

598

599 Figure 1: Evolution of sugars, ethanol, glycerol and biomass content in the absence (A)

600 or presence of residues of mepanipyrim (B) and tetraconazole (C) commercial 601 formulations.

602

603 Figure 2: Genes and proteins related to cell cycle repressed in the fermentations with 604 tetraconazole after 48 hours. Hits observed in the transcriptomic analysis are highlighted 605 in green, and those obtained from the proteomics analysis are highlighted in blue. The 606 different cell cycle phases are depicted in the inner circle, and the main events taking part 607 in every phase are represented in the outer circumference. Blue lines have been included 608 to classify the genes and proteins found according to the process in which they are 609 involved. The master regulator of the cell cycle in S. cerevisiae, Cdc28p, is represented 610 at the centre of the inner circumference, with different green arrows pointing at it, 611 meaning the regulation activity of proteins encoded by genes found in the analysis over 612 Cdc28p.

613

614 Figure 3: Biosynthesis of aromatic compounds in the absence (A) or presence of residues 615 of mepanipyrim (B) and tetraconazole (C) commercial formulations.

617 Figure 4: Genes and proteins involved in the Ehrlich and volatile ester formation 618 pathways overexpressed in the presence of tetraconazole after $48 \mathrm{~h}$ of fermentation. Hits 619 observed in the transcriptomic analysis are highlighted with a green frame, and those 620 obtained from the proteomics analysis are highlighted in blue. The differential expression 
621 of each gene in the presence (green line) and absence (blue line) of tetraconazole with 622 time were also included. 
Table 1. Indices used to describe the fermentation course in presence and absence of fungicides.

\begin{tabular}{|c|c|c|c|c|c|c|c|c|c|c|c|c|c|c|c|}
\hline & \multicolumn{9}{|c|}{ Exponential Growth Phase } & \multicolumn{6}{|c|}{ Stationary Phase } \\
\hline & \multicolumn{3}{|c|}{$\begin{array}{l}\text { Glucose and Fructose } \\
\text { consumption }\left(\mathbf{r}_{\mathrm{s}}\right)\end{array}$} & \multicolumn{3}{|c|}{$\begin{array}{c}\text { Maximum specific growth } \\
\text { rate }\left(\mu_{\max }\right)\end{array}$} & \multicolumn{3}{|c|}{$\begin{array}{l}\text { Ethanol production } \\
\qquad\left(\mathbf{r}_{\mathrm{e}}\right)\end{array}$} & \multicolumn{3}{|c|}{$\begin{array}{l}\text { Biomass to Ethanol Yield } \\
\qquad\left(Y_{E / B}\right)\end{array}$} & \multicolumn{3}{|c|}{$\begin{array}{l}\text { Sugars to Ethanol Yield } \\
\qquad\left(\mathbf{Y}_{E / S}\right)\end{array}$} \\
\hline & Mean & \pm & SD & Mean & \pm & SD & Mean & \pm & SD & Mean & \pm & SD & Mean & \pm & SD \\
\hline Control & $32.40^{\mathrm{a}}$ & \pm & 6.34 & $2.07^{\mathrm{a}}$ & \pm & 0.06 & $14.42^{b}$ & \pm & 0.12 & $5.40^{\mathrm{a}}$ & \pm & 0.27 & $0.37^{\mathrm{a}}$ & \pm & 0.01 \\
\hline Mepanipyrim & $19.14^{\mathrm{a}}$ & \pm & 3.11 & $2.05^{\mathrm{a}}$ & \pm & 0.11 & $15.00^{\mathrm{b}}$ & \pm & 1.44 & $5.59^{\mathrm{ab}}$ & \pm & 0.41 & $0.37^{\mathrm{a}}$ & \pm & 0.01 \\
\hline Tetraconazole & $29.83^{\mathrm{a}}$ & \pm & 1.55 & $2.15^{\mathrm{a}}$ & \pm & 0.02 & $12.42^{\mathrm{a}}$ & \pm & 0.59 & $5.93^{\mathrm{b}}$ & \pm & 0.26 & $0.40^{\mathrm{a}}$ & \pm & 0.01 \\
\hline
\end{tabular}




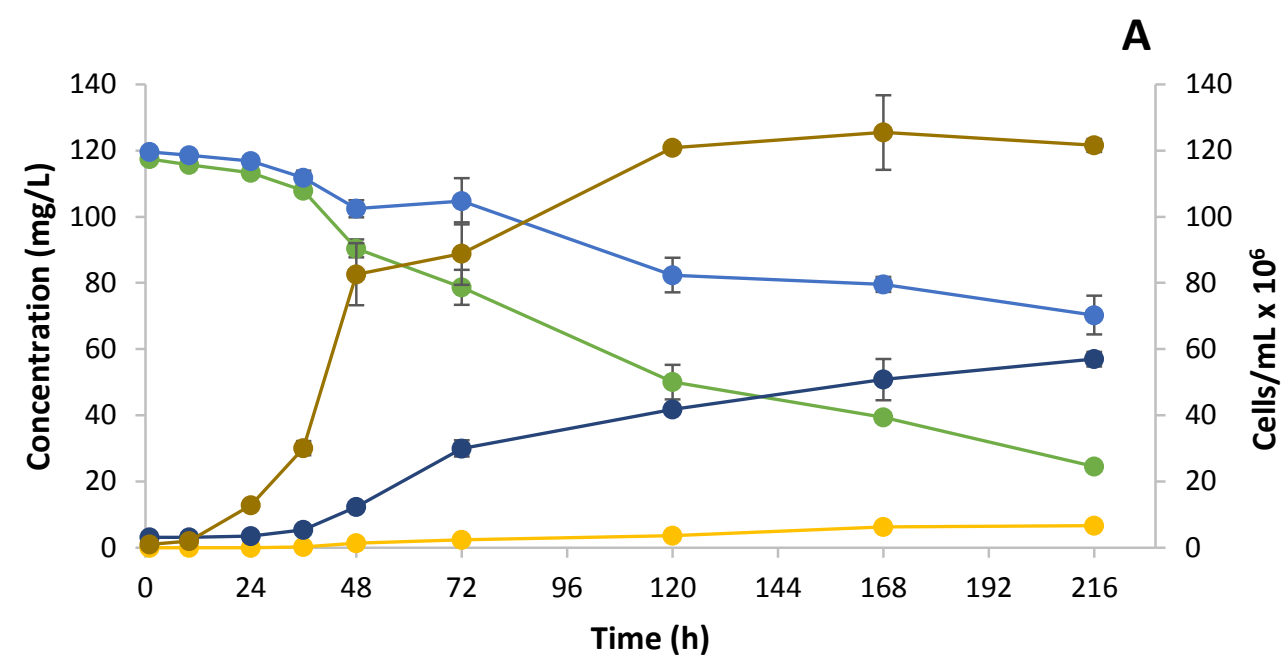

B

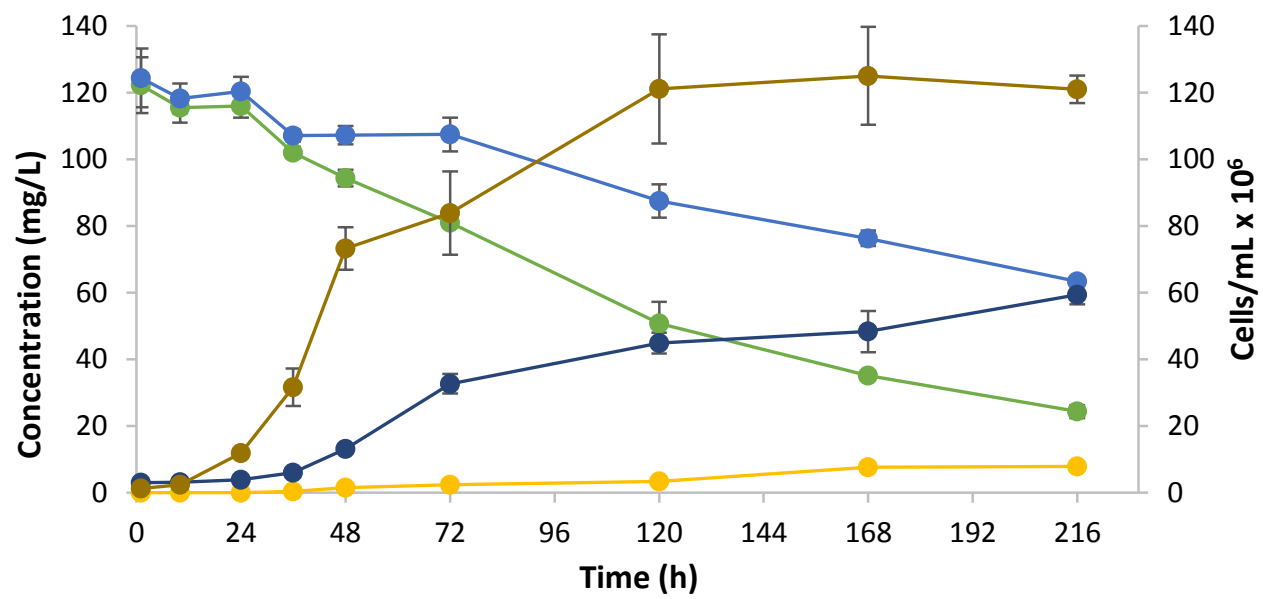

C

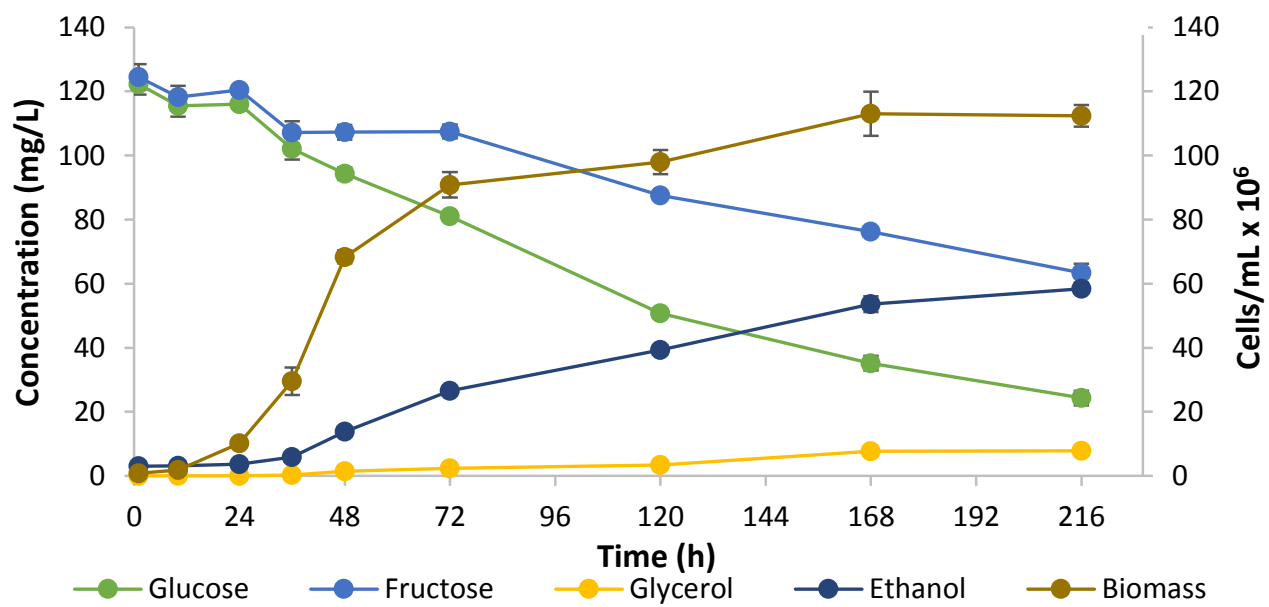

Figure 1: Evolution of sugars, ethanol, glycerol and biomass content in the absence (A) or presence of residues of mepanipyrim (B) and tetraconazole (C) commercial formulations. 


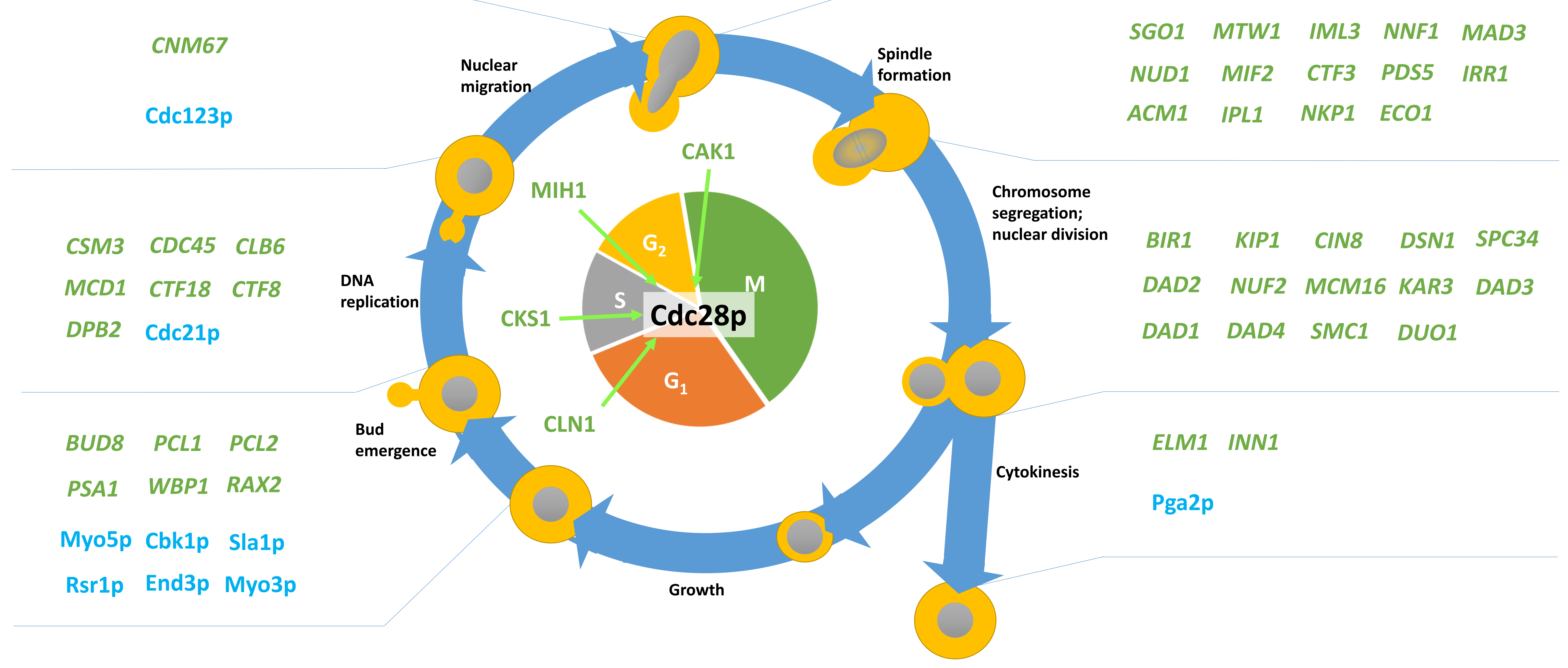



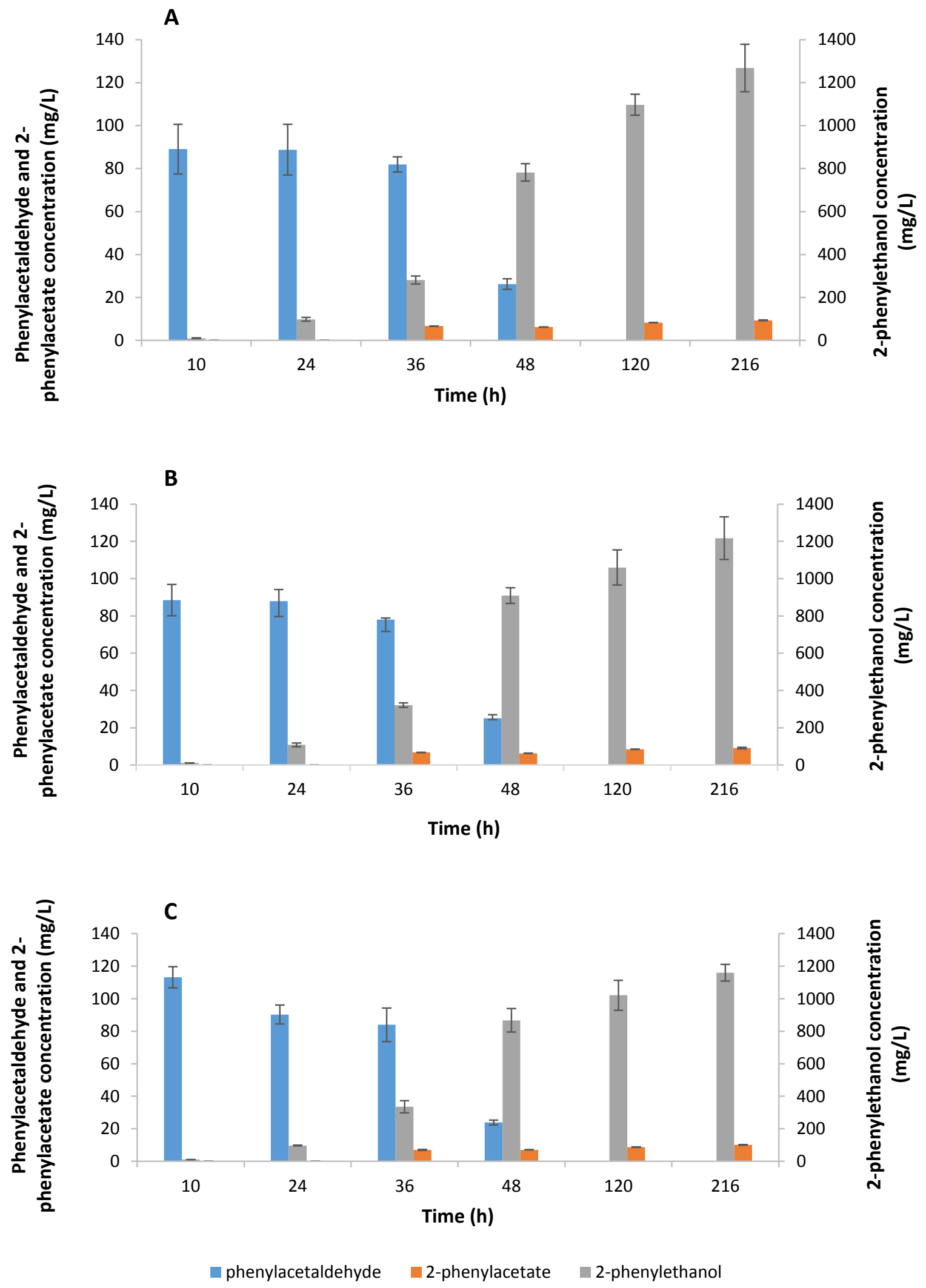

Figure 3: Biosynthesis of aromatic compounds in the absence (A) or presence of residues of mepanipyrim (B) and tetraconazole (C) commercial formulations. 


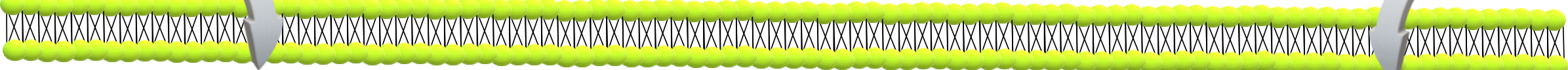

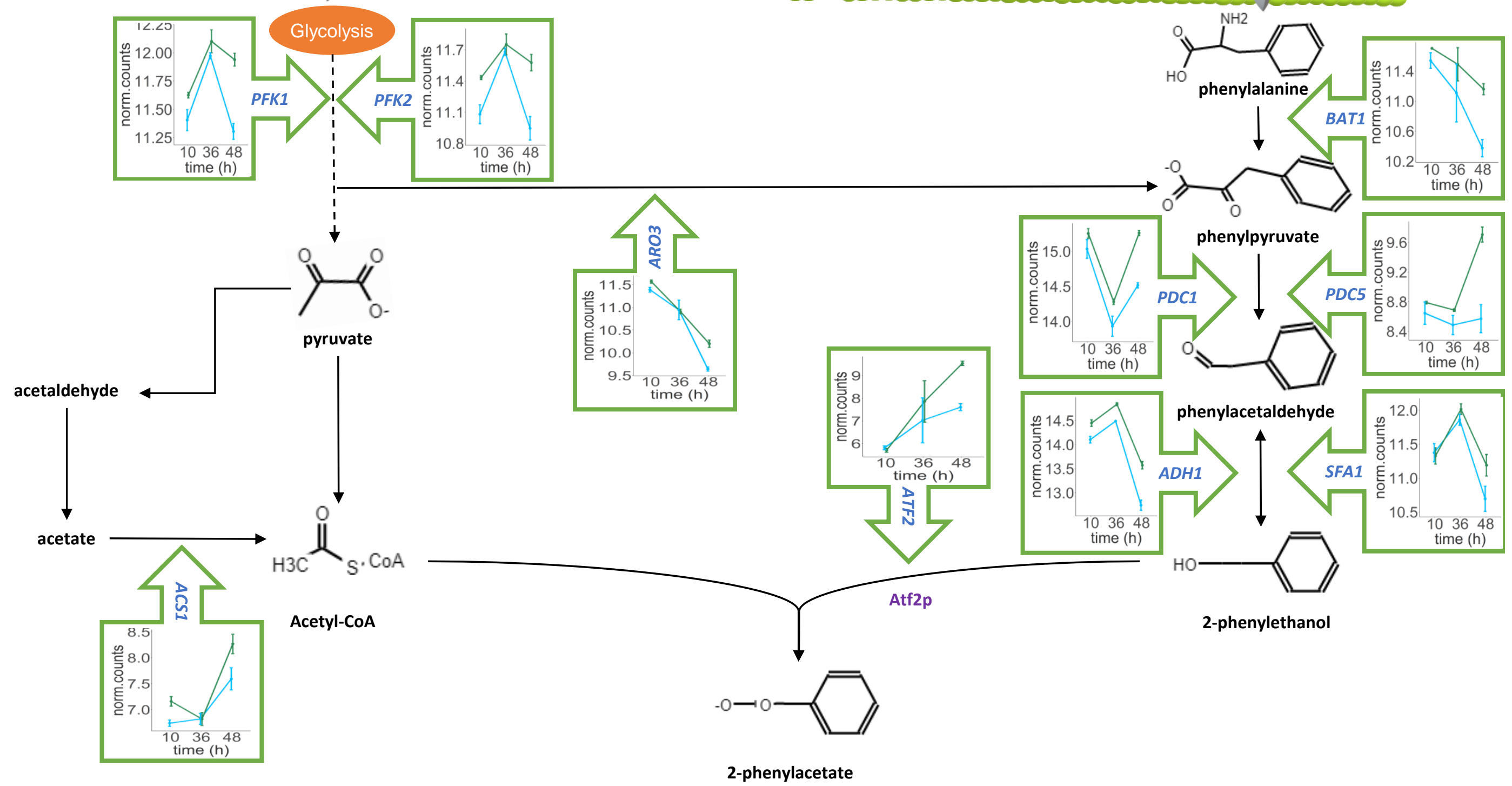

